\title{
PERANCANGAN RUMAH TINGGAL DUA LANTAI DENGAN KONSEP HEMAT ENERGI MELALUI PENDEKATAN ARSITEKTUR TROPIS
}

\author{
Ulinata ${ }^{1,2}$ Jihad Fisabilillah ${ }^{2}$ \\ ${ }^{1}$ Universitas Kristen Indonesia, email: ulinata@uki.ac.id \\ 2PT.Jiad Fisa Arta, email: jf.artha14@gmail.com
}

\begin{abstract}
A living house is one of the basic human needs. Currently, many residential houses are built without giving attention to environmental aspects and do not take into account the tropical climate in Indonesia, especially in the city of Medan. A solution is needed in designing a living house that considers the tropical climate. One of them is by designing a living house through a tropical architectural approach with the concept of energy saving. The research, entitled Two-Storey House with Energy Saving Concept through Tropical Architecture Approach, aims to design a two-storey house with an energy-efficient concept through a tropical architectural approach by taking into account existing conditions, building orientation, wind direction, natural lighting, natural ventilation. This study uses a qualitative descriptive method by determining the location, collecting article data from national journals obtained from the internet so as to get the variables used for design guidelines, conducting analysis by conducting visits to land locations that produce photo documentation and working drawings. This living house design is expected to be an example or recommendation for an energy-efficient residence through a tropical architectural approach.
\end{abstract}

\section{Keywords: Living House, Energy Saving, Tropical Architecture}

\begin{abstract}
Abstrak
Rumah tinggal adalah salah satu kebutuhan pokok manusia. Saat ini, banyak rumah tinggal dibangun tanpa memperhatikan aspek lingkungan dan tidak mempertimbangkan iklim tropis yang ada di Indonesia khususnya di Kota Medan. Diperlukan sebuah solusi dalam merancang rumah tinggal yang mempertimbangkan iklim tropis. Salah satunya yaitu dengan merancang rumah tinggal melalui pendekatan arsitektur tropis dengan konsep hemat energi. Penelitian yang berjudul Rumah Tinggal Dua Lantai dengan Konsep Hemat Energi melalui Pendekatan Arsitektur Tropis ini bertujuan untuk merancang rumah tinggal dua lantai dengan konsep hemat energi melalui pendekatan arsitektur tropis dengan memperhatikan kondisi eksisting, orientasi bangunan, arah angin, pencahayaan alami, penghawaan alami. Penelitian ini menggunakan metode deskriptif kualitatif dengan cara menentukan lokasi, mengumpulkan data artikel dari jurnal nasional yang diperoleh dari internet sehingga mendapatkan variabel yang digunakan untuk pedoman perancangan, melakukan analisis dengan melakukan kunjungan ke lokasi lahan yang menghasilkan dokumentasi foto serta gambar kerja. Perancangan rumah tinggal ini diharapkan dapat menjadi contoh atau rekomendasi rumah tinggal yang hemat energi melalui pendekatan arsitektur tropis.
\end{abstract}

\section{Kata-kunci : Rumah Tinggal, Hemat Energi, Arsitektur Tropis}

\section{Pendahuluan}

Rumah tinggal dapat diartikan sebagai sebuah bangunan yang menjadi tempat tinggal bagi manusia yang dibentuk dari beberapa ruang dan diberi pembatas dinding serta penutup atap (Rulli, 2014). Di Indonesia khususnya di kota Medan, permintaan akan kebutuhan rumah tinggal semakin meningkat dikarenakan pertumbuhan penduduk yang juga terus bertambah (Fisika et al., 2016). Oleh Karena itu dibutuhkan sebuah solusi agar kebutuhan rumah tinggal terpenuhi yaitu dengan melakukan pembangunan di sektor perumahan dengan maksimal. Namun, seringkali pembangunan tersebut dirancang tanpa memperhatikan unsur hemat energi sehingga mengakibatkan beban operasional listrik yang cukup tinggi yang memberikan dampak pemborosan energi (Karyono, 2011). Selain itu, bisa memberikan dampak pemanasan global dan kerusakan lingkungan sehingga dibutuhkan usaha untuk melakukan penghematan energi pada sebuah rumah tinggal dimana dalam perancangannya dapat memberikan kontribusi 
terhadap dampak pemanasan global dan lainnya (Prianto, 2007). Disamping itu juga perlu dipertimbangkan konsep arsitektur yang dipakai dalam perancangan agar dapat beradaptasi dengan kondisi iklim yang ada di Indonesia yaitu iklim tropis (Bu'ulolo et al., 2020). Arsitektur tropis adalah sebuah konsep arsitektur yang beradaptasi pada iklim tropis untuk diaplikasikan ke dalam sebuah bangunan (Edyas et al., 2017). Dalam merancang sebuah rumah tinggal konsep hemat energi melalui pendekatan arsitektur tropis terdapat beberapa permasalahan diantaranya yaitu mencari defenisi dari hemat energi dan arsitektur tropis, bagaimana menerapkan konsep hemat energi melalui pendekatan arsitektur tropis pada perancangan rumah tinggal, dan juga aspek apa saja yang perlu dipertimbangkan dalam merancang sebuah rumah tinggal yang menerapkan konsep hemat energi melalui pendekatan arsitektur tropis. Penelitian yang berjudul Perancangan Rumah Tinggal Dua Lantai dengan Konsep Hemat Energi Melalui Pendekatan Arsitektur Tropis ini bertujuan untuk mengetahui bagaimana menerapkan konsep hemat energi melalui pendekatan arsitektur tropis pada perancangan rumah tinggal yang hasilnya diharapkan menjadi sebuah contoh atau rekomendasi sebuah rumah tinggal yang menggunakan pendekatan arsitektur tropis yang hemat energi dan dapat memberikan kontribusi terhadap dampak pemanasan global, pemborosan energi dan kerusakan lingkungan.

\section{Tinjauan Pustaka}

\section{Rumah Tinggal}

Rumah tinggal merupakan bangunan yang dapat digunakan sebagai tempat tinggal dalam kurun waktu tertentu (Rulli, 2014). Saat ini penggunaan energi listrik pada rumah tinggal dikonsumsi secara berlebihan yang mengakibatkan pemborosan energi sehingga diperlukan strategi dalam merancang rumah tinggal dengan konsep hemat energi (Rahanra et al., n.d.). Beberapa strategi yang perlu ditekankan dalam merancang sebuah rumah tinggal dengan konsep hemat energi adalah pencegahan efek rumah kaca, pencegahan terhadap panas pada area atap bangunan, perletakan ruang penahan panas pada sisi timur dan barat bangunan, melakukan pencegahan terhadap jatuhnya panas matahari pada permukaan perkerasan serta pemanfaatan aliran udara di malam hari (Heryanto, 2004). Kota Medan adalah salah satu kota di Indonesia yang memiliki iklim tropis yang memiliki curah hujan dan suhu sehingga dalam merancang sebuah bangunan khususnya dengan fungsi rumah tinggal harus mampu menjawab permasalahan iklim tropis (Simbolon \& Nasution, 2017). Solusinya yaitu dengan merancang rumah tinggal dengan pendekatan arsitektur tropis yang hemat energi.

\section{Arsitektur Tropis}

Arsitektur tropis merupakan sebuah karya arsitektur yang memecahkan permasalahan terkait iklim setempat yaitu iklim tropis (Karyono, 2000). Beberapa peneliti terdahulu banyak yang membahas mengenai konsep arsitektur tropis pada bangunan. Penelitian bertama berjudul Konsep Arsitektur Tropis pada Green Building sebagai Solusi Hemat Biaya (Low Cost) yang menggunakan metode kualitatif deskriptif yang menyebutkan bahwa faktor-faktor yang mempengaruhi dalam merancang bangunan adalah kenyamanan thermal, aliran udara melalui bangunan serta radiasi panas (Edyas et al., 2017). Penelitian kedua berjudul Rumah Tropis Hemat Energi Bentuk Kepedulian Global Warming yang menggunakan metode pendekatan research and development dimana diperlukan strategi desain dalam merancang sebuah rumah tropis yang hemat energi diantaranya strategi desain sistem penerangan, pertimbangan orientasi, kondisi eksisting lokasi, kreatifitas dalam mengolah sisi fasade bangunan, eksplorasi iklim setempat, penggunaan material dan struktur, shading, serta elemen hijau (Prianto, 2007). Penelitian ketiga berjudul Konsep Ramah Lingkungan dalam Hunian dengan Memperhatikan Faktor Iklim di Daerah Tropis yang membahas mengenai hal-hal yang perlu diperhatikan ketika merancang hunian pada daerah yang beriklim tropis diantaranya radiasi matahari, orientasi bangunan, sunshading, penghijauan, pencahayaan dan sirkulasi udara yang baik (Mufliha et al., 2015). Ketiga penelitian sejenis yang sudah lebih dahulu dilakukan ini akan menjadi acuan dalam penelitian yang berjudul Perancangan Rumah Tinggal Dua Lantai dengan Konsep Hemat Energi Melalui Pendekatan Arsitektur Tropis sehingga nantinya akan menghasilkan suatu output desain dengan konsep desain yang dapat diaplikasikan di sebuah lokasi dan dapat menjadi sebuah contoh atau rekomendasi sebuah rumah tinggal yang menggunakan konsep hemat energi dengan pendekatan arsitektur tropis Perancangan Rumah Tinggal Dua Lantai di Perumnas Helvetia ini menerapkan konsep hemat energi dengan pendekatan arsitektur tropis

\section{Metode}

Penelitian yang berjudul Perancangan Rumah Tinggal Dua Lantai dengan Konsep Hemat Energi Melalui Pendekatan Arsitektur Tropis ini menggunakan metode kualitatif deskriptif yang dipakai pada penelitian pertama terdahulu yang berjudul Konsep Arsitektur Tropis pada Green Building sebagai Solusi Hemat Biaya (Low Cost) dengan beberapa tahapan diantaranya : 
e-ISSN 2685-1490; p-ISSN 2615-1472

\section{Metode Penentuan Lokasi}

Penentuan lokasi ditentukan berdasarkan ketersediaan lahan kosong sehingga rumah tinggal tersebut bisa terbangun setelah direncanakan dan dirancang. Lokasi berada di Perumnas Helvetia Medan karena masih tersedia lahan kosong dan pemilik lahan ingin menggunakan lahan tersebut untuk dijadikan sebuah rumah tinggal yang akan dihuni oleh pemilik lahan tersebut.

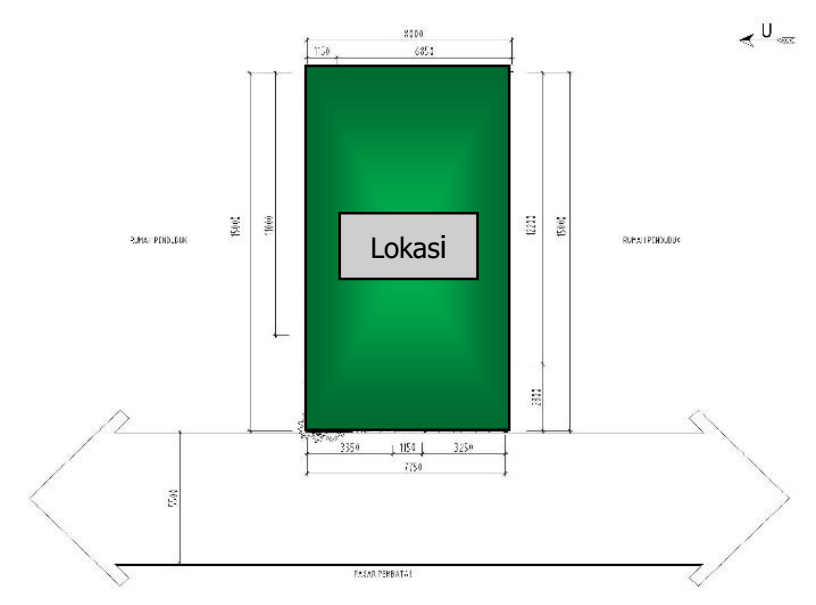

Gambar 1. Lokasi Penelitian (Sumber : Peneliti, 2021)

\section{Metode Pengumpulan dan Analisis Data}

Pengumpulan data diambil dari :

1. Wawancara mendalam dengan pemilik lahan dengan memberikan beberapa pertanyaan yang menghasilkan jawaban terkait kebutuhan ruang dan penerapan konsep hemat energi dengan pendekatan arsitektur tropis.

2. Artikel jurnal nasional, skripsi atau tugas akhir mahasiswa yang berkaitan dengan perancangan rumah tinggal dengan konsep hemat energi dengan pendekatan arsitektur tropis.

3. Lalu dari pengumpulan data tersebut kemudian dianalisis lalu diambil beberapa variabel yang digunakan dalam merancang sebuah rumah tinggal dengan konsep hemat energi dengan pendekatan arsitektur tropis. Pengumpulan data ini diakses melalui internet.

Tabel.1 Variabel penelitian

\begin{tabular}{|l|l|l|}
\hline No & \multicolumn{1}{|c|}{ Variabel } & \multicolumn{1}{c|}{ Sumber } \\
\hline 1 & Radiasi Panas & (Edyas et al., 2017) \\
\hline 2 & Elemen Hijau & (Prianto, 2007) \\
\hline 3 & Orientasi Bangunan & (Mufliha et al., 2015) \\
\hline 4 & $\begin{array}{l}\text { Pencahayaan dan Sirkulasi } \\
\text { Udara yang Baik }\end{array}$ & \\
\hline
\end{tabular}

4. Hasil analisis yang diperoleh melalui hasil kunjungan ke lokasi lahan setelah mengumpulkan data lalu mengelompokkan dan menginterpretasi data yang diperoleh yang menjadikan sebuah konsep perancangan. Alat yang digunakan pada saat analisis adalah kamera untuk mendokumentasikan foto-foto yang ada di lokasi lahan, kertas dan pinsil untuk mensketsa dan menulis hasil analisa. Analisa tersebut dilakukan pada hari seninminggu selama satu minggu hingga diperoleh hasil analisis secara keseluruhan.

\section{Analisis dan Interpretasi}

\section{Radiasi Panas}

Radiasi Panas disebabkan oleh sinar matahari yang masuk dari luar ke dalam rumah tinggal sehingga ruangan menjadi panas. Solusi untuk mengatasi radiasi panas adalah memberikan shading berupa kanopi pada bukaan berupa jendela atau pintu sehingga dapat mencegah radiasi panas masuk ke dalam rumah tinggal tersebut. 


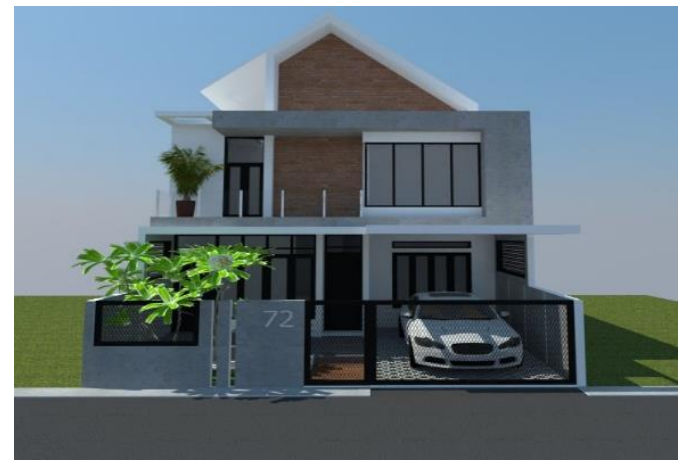

Gambar 2. 3D Rumah Tinggal Dua Lantai (Sumber : Peneliti, 2021)

Terlihat pada gambar di atas, pada tampak rumah tinggal, diberikan kanopi beton pada jendela dan pintu sehingga radiasi matahari tidak masuk secara keseluruhan ke dalam rumah tinggal tersebut. Hasilnya setelah dibangun dan dihuni dapat terlihat pada gambar 3.

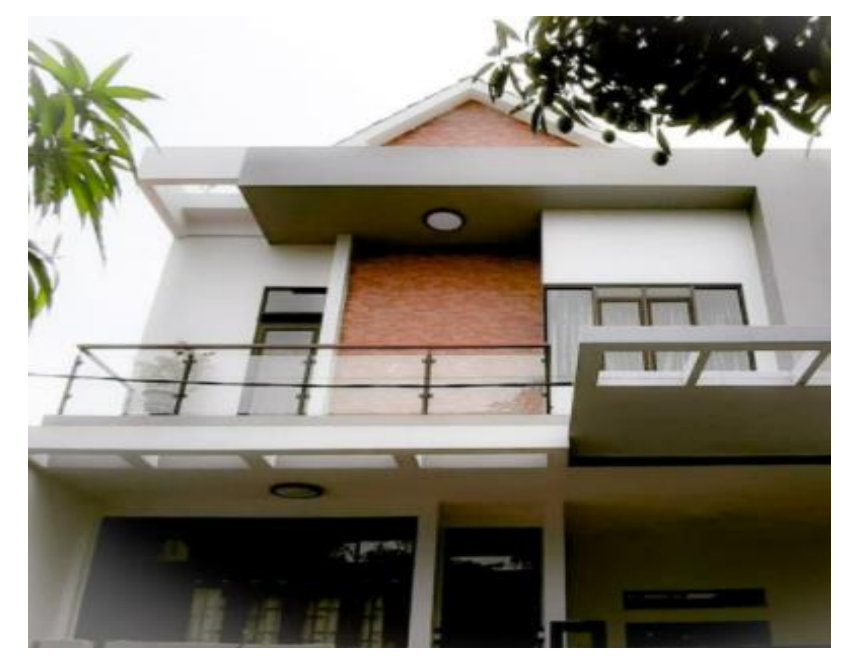

Gambar 3. Tampak Depan Rumah Tinggal Dua Lantai Setelah Dibangun dan Dihuni (Sumber : Peneliti, 2021)

\section{Elemen Hijau}

Menyediakan elemen hijau berupa innercourt sebagai ruang pengganti hijau pada lahan yang telah dipakai untuk membangun rumah tinggal tersebut. Juga menyediakan vegetasi berupa rumput dan pepohonan di area koefisien dasar hijau (KDH) yang telah ditetapkan (Gambar 4). 


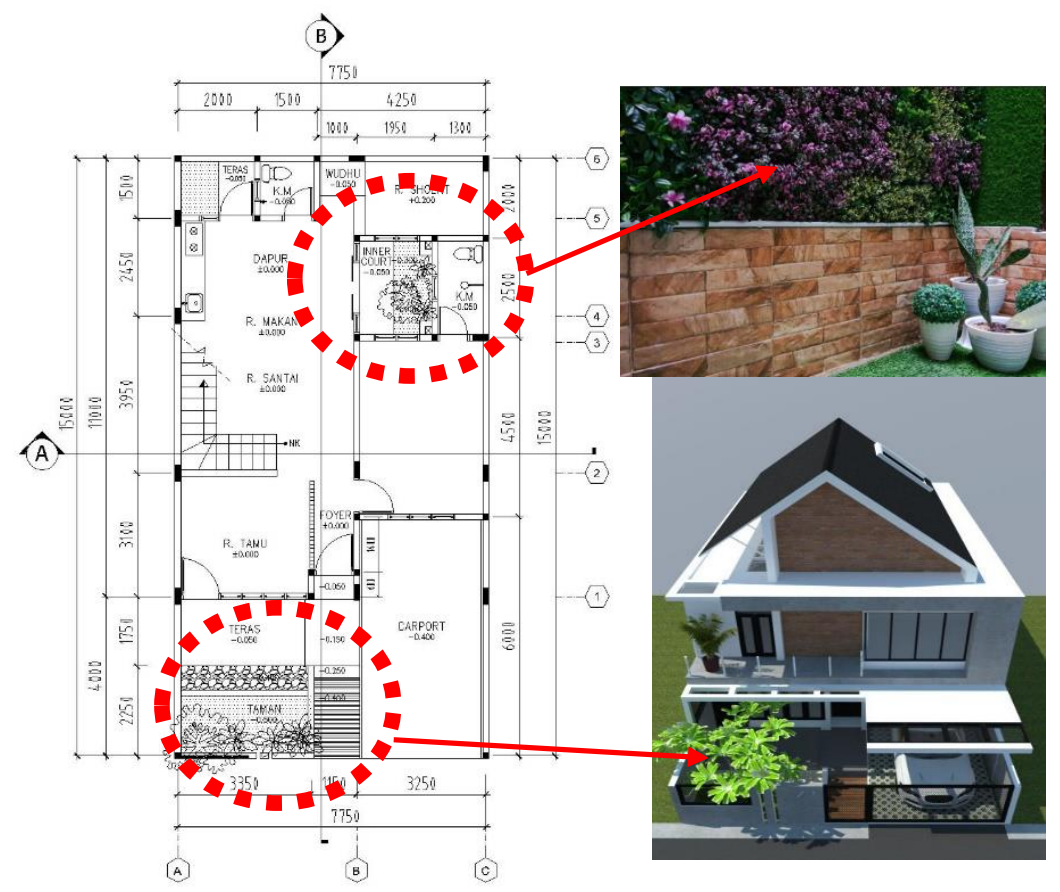

Gambar 4. Innercourt dan Pepohonan yang Ditanam di Depan Rumah Tinggal (Kiri) (Sumber : Peneliti, 2021) Hasilnya setelah dibangun dan dihuni dapat terlihat pada gambar 5 .
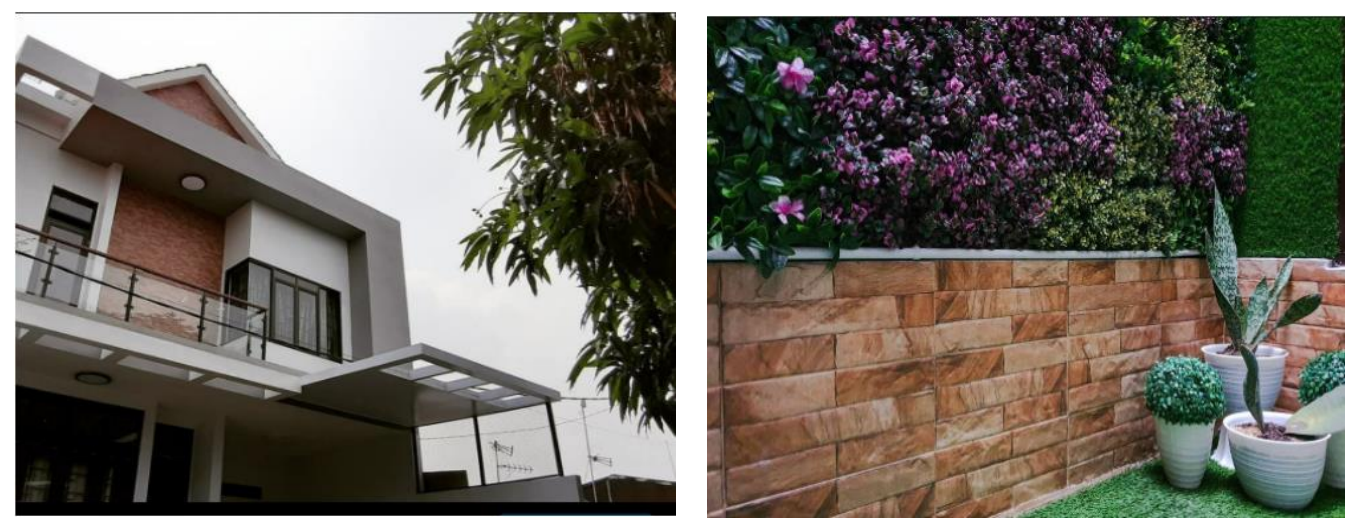

Gambar 5. Pepohonan yang Ditanam di Depan Rumah Tinggal (Kiri) dan Innercourt (Sumber : Peneliti, 2021)

Fungsi elemen hijau berupa pepohonan yang diletakkan di depan lahan adalah sebagai buffer atau penyangga agar panas dari luar tidak masuk secara menyeluruh ke rumah tinggal sehingga menjadi lebih sejuk dan tidak perlu memasang AC terutama di siang hari sehingga lebih hemat energi. Selain itu terdapat area hijau berupa rumput dan inner court yang dapat menambah kesejukan di dalam rumah tinggal tersebut.

\section{Orientasi Bangunan}

Orientasi Bangunan sebaiknya diletakkan ke arah bagian yang terlindungi dari panas matahari yaitu menghadap utara atau selatan. Jika orientasi bangunan menghadap ke arah barat atau timur sebaiknya diberikan shading dan tidak perlu menyediakaan banyak bukaan berupa jendela dan pintu. Orientasi rumah tinggal ini menghadap ke arah barat karena di sebelah utara dan selatan lahan tersebut terdapat bangunan berupa rumah tinggal. Jika tetap menghadap utara atau selatan maka rumah tinggal tidak terlalu banyak mendapatkan pencahayaan alami. Sehingga solusinya adalah dengan membuat orientasi rumah tinggal menghadap ke barat namun diberikan shading berupa kanopi pada bukaan berupa pintu dan jendela agar dapat mengurangi panas matahari yang masuk ke dalam 
rumah tinggal tersebut sehingga rumah tinggal tersebut tetap dalam suhu ruang yang nyaman dan tidak perlu menggunakan AC terutama pada siang hari sehingga lebih hemat energi.

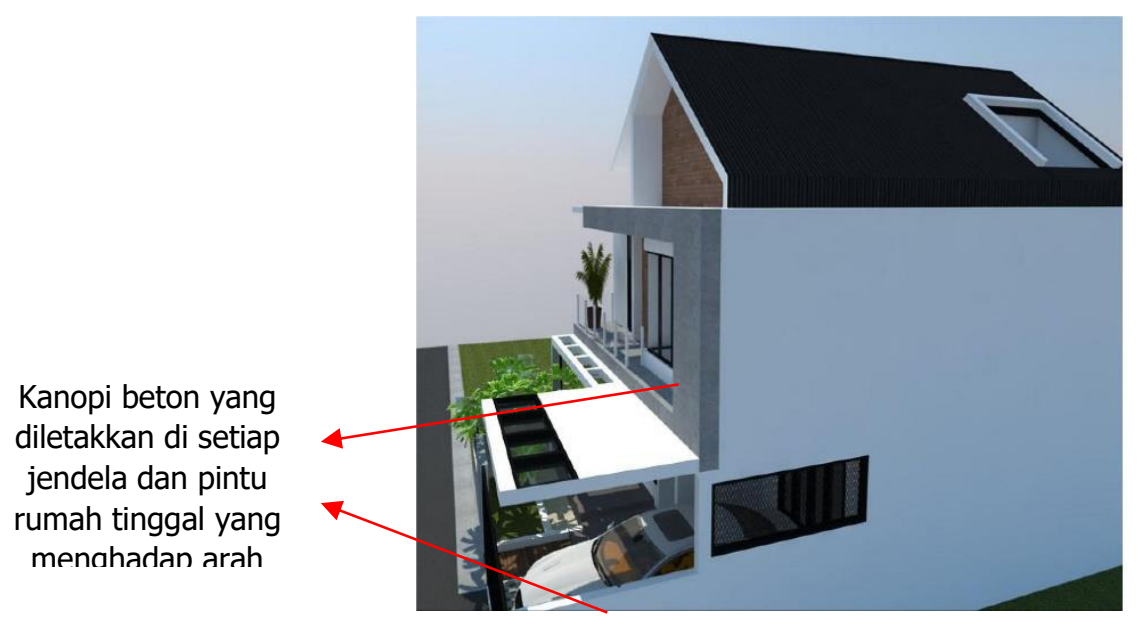

\section{Pencahayaan dan Sirkulasi yang Baik}

Pencahayaan yang baik dapat diterapkan dengan menyediakan ventilasi berupa jendela yang cukup besar dan penambahan skylight pada bagian atap bangunan dan diletakkan di tengah bangunan rumah tinggal agar cahaya yang masuk ke dalam rumah tinggal tersebut lebih optimal sehingga dapat mengurangi penggunaan lampu di siang hari sehingga lebih hemat energi. Jenis lampu yang digunakan adalah lampu LED yang hemat energi yang digunakan pada malam hari saja. Sirkulasi yang baik juga dapat diterapkan dengan penempatan bukaan berupa jendela dan pintu dengan sistem ventilasi silang (cross ventilation) sehingga udara dari luar dapat masuk dan dialirkan ke dalam ruang pada rumah tinggal tersebut.
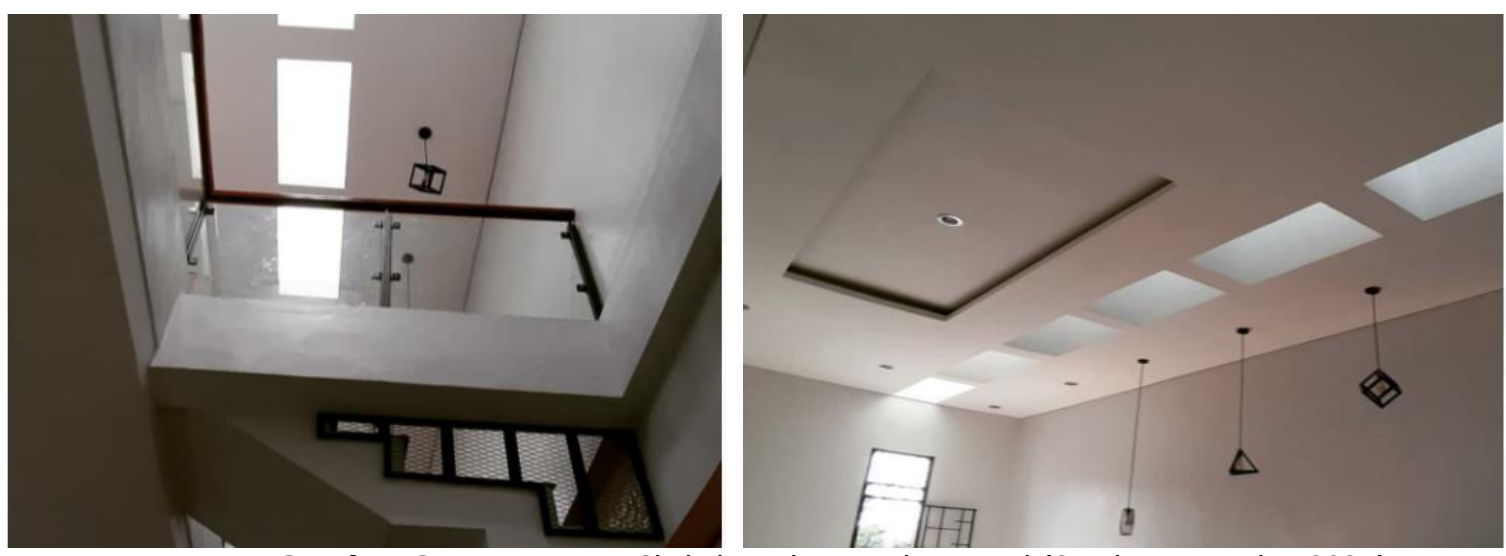

Gambar 6. Penggunaan Skylight Pada Rumah Tinggal (Sumber : Peneliti, 2021)

\section{Kesimpulan dan Saran}

Perancangan Rumah Tinggal Dua Lantai di Perumnas Helvetia ini menerapkan konsep hemat energi dengan pendekatan arsitektur tropis dengan beberapa strategi diantaranya memberikan shading berupa kanopi pada setiap bukaan yang berupa jendela dan pintu, menyediakan elemen hijau berupa pepohonan, rumput dan iinercourt agar menjadi buffer atau penyangga bangunan rumah tinggal terhadap panas matahari yang masuk ke dalam bangunan dan juga dapat menambah kesejukan, orientasi bangunan yang menghadap barat yang disiasati dengan kanopi beton yang diletakkan di jendela dan pintu rumah bagian depan, pencahayaan dan sirkulasi yang baik berupa cross ventilation dan skylight agar cahaya dan udara masuk secara optimal sehingga tidak membutuhkan pencahayaan buatan berupa lampu di siang hari dan penghawaan buatan berupa AC. Perancangan Rumah Tinggal Dua Lantai dengan konsep hemat 
energi dan melalui pendekatan arsitektur tropis ini diharapkan dapat menjadi contoh atau rekomendasi dalam merancang sebuah rumah tinggal khususnya di kota Medan dan dapat memberikan kontribusi terhadap dampak pemanasan global, pemborosan energi dan kerusakan lingkungan.

\section{Ucapan Terima Kasih}

Puji dan syukur Penulis panjatkan ke hadirat Tuhan Yang Maha Esa atas berkat-Nya, Penulis dapat menyelesaikan Penelitian yang berjudul Perancangan Rumah Tinggal Dua Lantai dengan Konsep Hemat Energi Melalui Pendekatan Arsitektur Tropis. Penulis juga mengucapkan terimakasih kepada :

1. Universitas Kristen Indonesia.

2. Bapak Dr. Dhaniswara K. Harjono, SH., MH., MBA, sebagai Rektor Universitas Kristen Indonesia.

3. LPPM Universitas Kristen Indonesia.

4. Ibu Ir.Galuh Widati, M.Sc, sebagai Dekan Fakultas Teknik Universitas Kristen Indonesia.

5. Bapak Ir.Setiyadi, MT selaku Ketua LPPM di Fakultas Teknik Universitas Kristen Indonesia.

6. Rekan Dosen Program Studi Arsitektur Fakultas Teknik UKI

7. PT.Jiad Fisa Artha yang telah membantu memberikan data terkait rumah tinggal yang dijadikan sebagai objek penelitian.

Semoga artikel dalam Penelitian ini dapat bermanfaat bagi kita semua.

\section{Daftar Pustaka}

Bu'ulolo, F. F., Silitonga, S., \& Yulianto. (2020). Bangunan Kolonial Studi Kasus: Museum Perkebunan Indonesia. Jurnal Arsitektur ALUR, 3(1), 39-43. http://ejournal.ust.ac.id/index.php/ALUR/article/view/677/pdf233

Edyas, A., Daming, T., \& Syarif, E. (2017). Konsep Arsitektur Tropis pada Green Building sebagai Solusi Hemat Biaya ( Low Cost JVWVWVWVWV. H033-H040. https://doi.org/10.32315/ti.6.h033

Fisika, D., Matematika, F., Ilmu, D. a N., Alam, P., \& Utara, U. S. (2016). Universitas Sumatera Utara - Beranda. 4-16. https://www.usu.ac.id/id/

Heryanto, S. (2004). Arsitektur Bangunan Hemat Energi. Jurnal IImiah Arsitektur UPH, 1(July), 14.

Karyono, T. H. (2000). Mendefinisikan kembali Arsitektur tropis di Indonesia. Desain Arsitektur, 1(April 2000), 7-8.

Karyono, T. H. (2011). Bangunan hemat energi. 8, 40561.

Mufliha, A., Puarada, I., \& Nirwansjah, R. (2015). Konsep Ramah Lingkungan dalam Hunian dengan Memperhatikan Faktor Iklim di Daerah Tropis. 1(1), 1-3.

Prianto, E. (2007). Rumah Tropis Hemat Energi Bentuk Kepedulian Global Warming. Riptek, 1(1), 1-10.

Rahanra, N., Sadjad, R. S., \& Zainuddin, Z. (n.d.). SISTEM KENDALI PEMAKAIAN LISTRIK PADA RUMAH BIASA EKEKTRICAL CONTROL SYSTEMS FOR USE IN HOUSE REGULAR Bagian Teknik Informatika , Universitas Satya Wiyata Mandala Nabire , 2 Bagian Teknik Alamat Korespondensi : Nicodemus Rahanra Program Studi Teknik Infor.

Rulli. (2014). Merencanakan Dan Merancang Rumah Tinggal Yang Optimal. Jurnal Teknik Sipil Dan Arsitektur, 15(19).

Simbolon, H., \& Nasution, I. N. (2017). Desain Rumah Tinggal Yang Ramah Lingkungan Untuk Iklim Tropis. Educational Building, 3(1), 46-59. https://doi.org/10.24114/eb.v3i1.7443 